\title{
Calcium Carbide Residue and Rice Husk Ash for improving the Compressive Strength of Compressed Earth Blocks
}

Philbert Nshimiyimana ${ }^{1,2}$, David Miraucourt ${ }^{2}$, Adamah Messan ${ }^{1}$, Luc Courard ${ }^{2}$

${ }^{1}$ Institut International d'Ingénierie de l'Eau et de l'Environnement (2iE), Laboratoire Eco-Matériaux de Construction (LEMC), Rue de la Science, 01, BP 594 Ouagadougou 01, Burkina Faso.

${ }^{2}$ Université de Liège (ULiège), Urban and Environmental Engineering (UEE), Laboratoire des Matériaux de Construction (LMC), Allée de la Découverte, 9, 4000 Liège, Belgique.

\begin{abstract}
Earth stabilization, using two by-products available in Burkina Faso: Calcium Carbide Residue (CCR) and Rice Husk Ash (RHA), improved the performance of compressed earth blocks (CEBs). The effect of adding CCR or CCR: RHA (in various ratios) to the clayey earth was investigated. CEBs were molded by manually compressing moisturized mixtures of earthen materials and 0-15\% CCR or CCR: RHA (various ratios) with respect to the weight of earthen material. The results showed that, with $15 \%$ CCR: RHA in 7: 3 ratio, the compressive strength of CEBs (6.6 MPa) is three times that of the CEBs containing $15 \% C C R$ alone $(2.2 \mathrm{MPa})$. This improvement was related to the pozzolanic reaction between CCR, clay and RHA. These CEBs comply with the requirement for wall construction of two-storey housing.
\end{abstract}

Corresponding author: Philbert Nshimiyimana, E-mail: pnshimiyimana@doct.uliege.be

\section{Introduction}

Depending on the quality of the available raw earth and required performance, stabilization is often undertaken to enhance the suitability of compressed earth blocks (CEBs). Among many other techniques, the addition of chemical binders such as cement, lime, pozzolan and geopolymers can be successfully performed [1-5]. Cement hydration results in formation of calcium silicate hydrates $(\mathrm{CSH})$ and eventually calcium aluminate hydrates $(\mathrm{CAH})$ responsible for binding the earth particles into the matrix and improve the performance of CEBs. Lime reacts with silica and alumina from the earth and pozzolan eventually for developing, with time, the cementitious products [1-4].

By-product such as calcium carbide residue (CCR) can potentially be used for stabilization of geotechnical soil [6]. The CCR is a white greyish by-product containing up to $90 \%$ hydrated lime $\left(\mathrm{Ca}(\mathrm{OH})_{2}\right)$. Equation 1 shows its formation from the hydrolysis of calcium carbide $\left(\mathrm{CaC}_{2}\right)$ during acetylene gas production [7]. Rice husk ash (RHA), another by-product, was reported to have pozzolanic activity in cement and concrete 
applications [8]. When RHA is formed in controlled condition of temperature (400$700^{\circ} \mathrm{C}$ ), time (1-6 hours) and environment (oxidizing); it can contain up to $80 \%$ of reactive silica [9].

$$
\mathrm{CaC}_{2}{ }^{(s)}+2 \mathrm{H}_{2} \mathrm{O}^{(l)} \rightarrow \mathrm{C}_{2} \mathrm{H}_{2}{ }^{(g)}+\mathrm{Ca}(\mathrm{OH})_{2}^{(a q .)}+64 k c a l
$$

Clearly, the application of CCR was mainly limited to the stabilization of geotechnical soil and that of RHA to cement and concrete. Additionally, little knowledge is available about CCR and RHA found in Burkina Faso and their potential applications. In this study, the characteristics and possibility to use the CCR and RHA for stabilizing CEBs were investigated. The experiments aimed to produce CEBs for load bearing in walls of two-storey housing. A pozzolanic reaction was expected from clay-CCR and CCR-RHA interactions. This interaction was evaluated based on compressive strength of CEBs with various contents of CCR or CCR: RHA.

\section{Experimental methods}

\section{$\underline{\text { Raw materials }}$}

The raw earth is reddish clayey soil extracted from Kamboinsé (N12²9.399', W001 $32.981^{\prime}$, alt. $322 \mathrm{~m}$ ). Its lumps were softly crushed to free elemental particles. It was sieved to eliminate the oversize on $5 \mathrm{~mm}$ for facilitating homogeneous mixing and interaction with the binder. The CCR was collected from Burkina Industrial Gas in

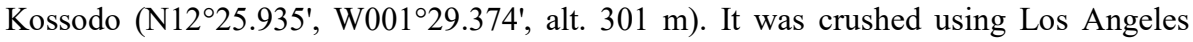
Machine and ball milled until $90 \%$ of particles are finer than $125 \mu \mathrm{m}$. The rice husk was collected from Bagre locality $\left(\mathrm{N} 11^{\circ} 28.43^{\prime}\right.$, W00 $32.12^{\prime}$, alt. $\left.233 \mathrm{~m}\right)$ and incinerated at $400^{\circ} \mathrm{C}$ for 4 hours in muffle furnace to form grey colored RHA. The RHA was ball milled until $95 \%$ of particles are finer than $80 \mu \mathrm{m}$.

\section{Mix design, molding and curing of compressed earth blocks}

Firstly, different fractions of CCR (0 to 15 weight \%) were added to the earth to evaluate the effect of CCR on CEBs and its optimum compressive strength. Secondly, CCR (10 and $15 \%)$ at different substitution rates with RHA (10 to $40 \%$ ), i.e CCR: RHA in $9: 1,8: 2,7: 3,6: 4$ ratios, was added to the earth in order to understand the impact of the interaction between CCR and RHA. Dry mixing of solid particles (Earth, CCR and/or RHA) was undertaken until occurrence of apparent homogeneity. The appropriate amount of water, equivalent to the optimum water content, was added and the mixing was carried on. For each mix, enough materials were prepared for the molding of at least 3 test specimens $\left(14 \times 14 \times 9.5 \mathrm{~cm}^{3}\right)$. The specimens were sealed and cured in ambient condition $\left(30 \pm 5^{\circ} \mathrm{C}\right)$ for 45 days, for the reaction to take place between clay and lime.

\section{Characterization and testing}

\section{Physico-chemical and mineral characterization of raw materials}

The particle size distribution (PSD), Atterberg's limits, and modified proctor test of the earth were determined in accordance with NF P 18-056 [10] and NF P 94-057 [11], NF P 94-051 [12] and NF P 94-093 [13], respectively. The PSD of CCR and RHA was analyzed by laser diffraction using Mastersizer analyser machine equipped with 
Mastersizer $2000 \mathrm{~V}$ analysis software and liquid dispersant hydro 2000s [14]. The specific surface area was determined according to BET methods by Nitrogen adsorption using micrometrics Gemini V1.01 instrument [15].

The chemical composition was analyzed by means of X-Ray Fluorescence technique using ARL Perform'X Sequential XRF equipment. The mineral composition was analyzed by X-Ray diffraction technique performed using Bruker D8-Advance Eco $1.5 \mathrm{~kW}$ diffractometer equipped with copper anticathode $(\mathrm{Cu} \mathrm{K \alpha} \lambda=1.54060 \AA, 40 \mathrm{kV}$, $25 \mathrm{~mA}$ ) and Lynxeye xe detector in coupled $2 \theta / \theta$ mode. The qualitative and semiquantitative analyses of the spectra were respectively done using Diffrac.Eva V4.11 and Topas V5 software of the Bruker based on Rietveld refinement method. The mineral composition was further confirmed by mean of thermogravimetric analysis (TGA). The TGA was carried out using automatic Multiple Sample Thermogravimetric Analyzer TGA-2000. The analysis was carried out in $25-1000^{\circ} \mathrm{C}$ range with heating rate of $5^{\circ} \mathrm{C}$.

The reactivity of RHA was determined according to the method proposed by Mehta [16]. About $1 \mathrm{~g}$ of the powder was boiled in $200 \mathrm{~mL}$ of $0.5 \mathrm{M}$ solution of $\mathrm{NaOH}$ for $3 \mathrm{~min}$. The amount of the RHA which dissolved is related to the amorphous reactive silica content in the RHA.

Mechanical testing of compressed earth blocks

The compressive strength was tested using hydraulic press equipped with a 300 $\mathrm{kN}$ capacity load cell at loading rate of $0.25 \mathrm{kN} / \mathrm{s}$. The test was carried out according to XP P13-901 [17] and calculation in equation 2. Where, $R_{c}$ is the compressive strength $(\mathrm{MPa}), \mathrm{F}_{\mathrm{r}}$ is the maximum load to failure $(\mathrm{kN})$, and $\mathrm{S}$ is the applied surface area $\left(\mathrm{cm}^{2}\right)$.

$$
R_{c}=10 * F_{r} / S
$$

\section{Results and discussion}

\section{$\underline{\text { Physico-chemical and mineral characteristics of raw materials }}$}

\section{Earthen material}

The particle size distribution (PSD) is presented in Figure $1 \mathrm{a}$ : this is fitting the CRATerre [4] recommended boundaries for lime stabilization for CEBs. The earth has a median diameter $\left(\mathrm{D}_{50}\right)$ of $30 \mu \mathrm{m}$ and contains $30 \%$ of clay particles, $59 \%$ of silt and sand, and $11 \%$ of gravel. It has plasticity index of 16 (limit of liquidity of 45), specific density of 2.75 and maximum dry density of $1.76 \mathrm{~g} / \mathrm{cm}^{3}$ at optimum water content of $17.4 \%$. Its chemical composition revealed mainly silica (51\%), alumina (24\%) and iron (III) oxides (13\%). The XRD spectrum (Figure 2 a) shows that earth contains mainly kaolinite clay, quartz and goethite estimated at $76 \%, 11 \%$ and $9 \%$, respectively. The TGA (Figure $2 \mathrm{~b}$ ) recorded loss of weight at around $310{ }^{\circ} \mathrm{C}\left(250-350{ }^{\circ} \mathrm{C}\right)$ and $549{ }^{\circ} \mathrm{C}$ $\left(425-690{ }^{\circ} \mathrm{C}\right.$ ) corresponding to the dehydration and dehydroxylation of goethite and kaolinite, respectively: the thermal removing of hydroxyl is indeed reported occurring around $290-330{ }^{\circ} \mathrm{C}$ and $530-590{ }^{\circ} \mathrm{C}$ for goethite and kaolinite, respectively [18].

Calcium carbide residue

The PSD of CCR presented in Figure $1 \mathrm{~b}$ shows $\mathrm{D}_{50}$ of $20.5 \mu \mathrm{m}$ and a rather plurimodal PSD around 10-100 $\mu \mathrm{m}$ with $90 \%$ of particles being finer than $125 \mu \mathrm{m}$. BET specific surface area and specific density are $14 \mathrm{~m}^{2} / \mathrm{g}$ and 2.49 , respectively. Chemical composition showed the predominance of $\mathrm{CaO}(67 \%)$ and total loss on ignition (LOI) of $26 \%$. The mineral composition of CCR (Figure 2 a) revealed the presence of portlandite $(43 \%)$. Portlandite $\left(\mathrm{Ca}(\mathrm{OH})_{2}\right)$ is the one responsible for the lime treatment of clayey soil 
$[4,6]$. The CCR also contains carbonate minerals such as aragonite $(20 \%)$, calcite $(16$ $\%$ ) and rapidcreekite $(13 \%)$. The TGA curve (Figure $2 \mathrm{~b}$ ) is characterized by important loss of weight at $512{ }^{\circ} \mathrm{C}\left(425-550{ }^{\circ} \mathrm{C}\right)$ and $815^{\circ} \mathrm{C}\left(675-875{ }^{\circ} \mathrm{C}\right)$ related to the dehydration of portlandite and decomposition of calcite, respectively, justifying its high LOI. Similar thermal behavior of CCR was previously reported between $400-620^{\circ} \mathrm{C}$ and $620-900{ }^{\circ} \mathrm{C}$, respectively [7].

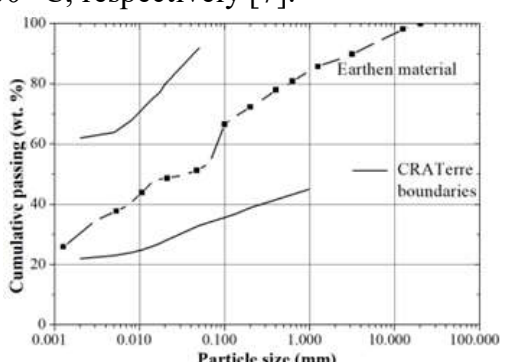

(a)

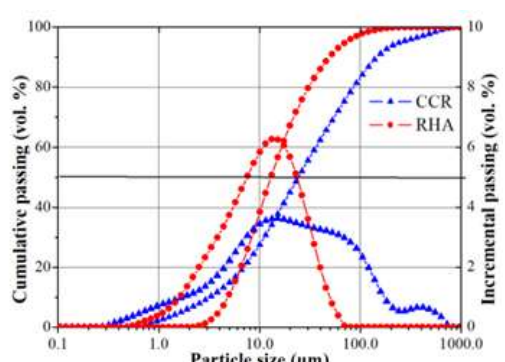

(b)

Figure 1. Particle size distribution of materials (a) raw earth and CRATerre recommended boundaries for lime stabilization (b) CCR and RHA after grinding.

Rice husk ash

Figure $1 \mathrm{~b}$ shows that RHA is finer than CCR with $\mathrm{D}_{50}$ of $11 \mu \mathrm{m}$ and monomodal PSD concentrated around $10 \mu \mathrm{m}$. It has BET surface area of $115 \mathrm{~m}^{2} / \mathrm{g}$ and specific density of 2.24. The XRD spectrum of RHA shows broad peak around $22^{\circ} 2 \theta$ revealing its amorphous nature with some quartz impurity (Figure 2 a). The chemical composition shows that RHA contains $90 \%$ of total silica. The reactive fraction of silica was found to be $68 \%$ which is in agreement with the observations of Muthadhi [9]. The loss of weight of RHA was mainly observed around $104{ }^{\circ} \mathrm{C}$ due to the dehydration of adsorbed water (Figure 2 b).

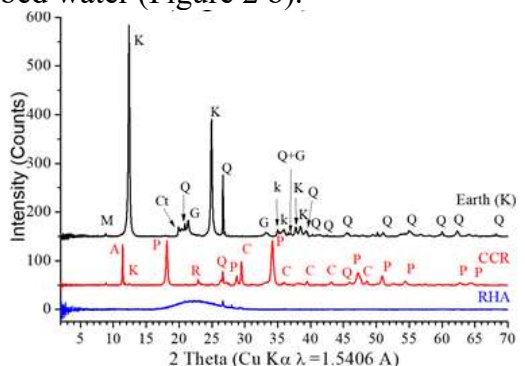

(a)

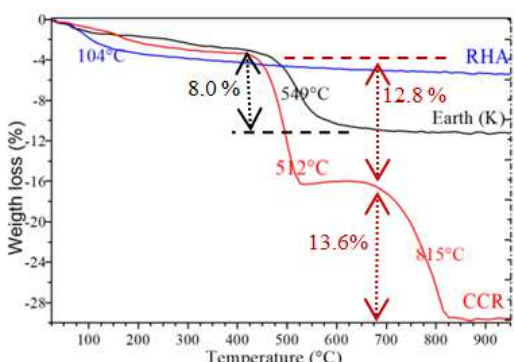

(b)

Figure 2. (a) XRD spectra and (b) TGA of raw materials; $\mathrm{Ct}$ : Total clay, $\mathrm{K}=$ Kaolinite, $\mathrm{Q}=\mathrm{Quartz}, \mathrm{G}=\mathrm{Goethite}, \mathrm{M}=\mathrm{Mica}$, $\mathrm{P}=$ Portlandite, $\mathrm{A}=$ Aragonite, $\mathrm{C}=$ Calcite, $\mathrm{R}=$ Rapidcreekite.

\section{Compressive strength of compressed earth blocks}

The addition of CCR to the earth resulted in important improvement of the compressive strength of the CEBs (Figure 3 a). The optimum content of CCR is corresponding to $8 \%$ where the compressive strength almost doubled to $3.4 \mathrm{MPa}$ from 
1.9 MPa of the control mix (0\% CCR). This improvement effect was related to the pozzolanic interaction between earth particles, mainly clay sized, with the CCR. Excess CCR (more than $8 \%$ ) resulted into detrimental effect due to the lack of effective interaction. Therefore, the zone below $8 \%$ CCR addition can be defined as improvement zone while the one beyond $8 \%$ is a detrimental zone for this particular earthen material.

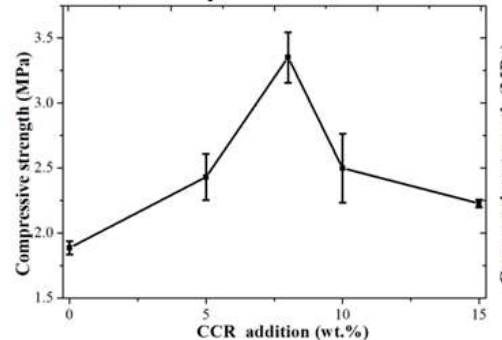

(a)

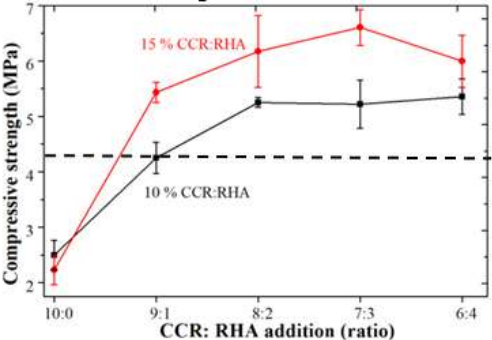

(b)

Figure 3. Dry compressive strength of CEBs stabilized with (a) CCR and (b) CCR partially substituted by RHA.

The compressive strength in the detrimental zone was further improved by partial substitution of CCR by RHA (Figure $3 \mathrm{~b}$ ). In this case, there is potential interaction between RHA and the excess CCR. It was indeed observed that for $10 \%$ CCR, the substitution with $20 \%$ RHA (i.e. $10 \%$ CCR: RHA in 8: 2 ratio) resulted in a compressive strength $(5.3 \mathrm{MPa})$ twice higher than that of CEBs with only $10 \% \mathrm{CCR}(2.5$ $\mathrm{MPa})$. On the other hand, in the case of $15 \% \mathrm{CCR}$, the maximum compressive strength (6.6 MPa) was achieved with $30 \%$ RHA substitution (15\% CCR: RHA in 7: 3) which is three times 2.2 MPa achieved when $15 \% \mathrm{CCR}$ was used alone.

In the first stage, a fraction of CCR added to the earth reacts with the clay and produces cementitious compounds which bind earth particles (improvement zone). The excess of unreacted CCR particles remains in between "cemented" zone and reduces the binding efficiency, thus reducing the compressive strength (detrimental zone). The presence of RHA in the mix favors more pozzolanic reaction with CCR and results in more cementitious products which further improves the compressive strength. Similar behavior was reported by Horpibulsuk [6] on the stabilization of silty soil with CCR and fly ash. From this study, the CEBs stabilized by $10 \%$ CCR: RHA in 9:1 ratio exceeded the dry compressive strength of $4 \mathrm{MPa}$ (Figure $3 \mathrm{~b}$ ). This is the minimum required by the ARS 673: 1996 and ARS 674: 1996 [19] to bear load in two-storey housing.

\section{Conclusions}

The compressive strength of CEBs was improved by the addition of CCR or CCR: RHA. This is related to the pozzolanic reaction between CCR with clay and RHA. The following conclusions can be reached from the present investigation:

1. The maximum compressive strength (3.4 MPa) of CEBs was reached with $8 \%$ CCR addition to the earthen material;

2. The compressive strength of CEBs was further improved by partial substitution of CCR with RHA, allowing 6.6 MPa at $15 \%$ CCR: RHA in 7: 3 ratio;

The results from this study imply that CEBs stabilized with 10\% CCR: RHA in 9:1 ratio reached the compressive strength of $4 \mathrm{MPa}$ required for bearing load in two-storey 
housing. Nevertheless, further studies are needed to investigate the performance of CCR: RHA stabilized CEBs at early age and their long term durability.

\section{Acknowledgement}

The « Académie de recherche et de l'enseignement supérieur de la Fédération WallonieBruxelles (Belgium)- Commission de la coopération au développement (ARES-CCD)» provided the financial support to this study as part of an international research and development project « Improving the quality of earthen housing in Burkina Faso ».

\section{REFERENCES}

[1] E. Ouedraogo, O. Coulibaly, A. Ouedraogo, and A. Messan, "Mechanical and Thermophysical Properties of Cement and/or Paper (Cellulose) Stabilized Compressed Clay Bricks," J. Mater. Eng. Struct. 2, vol. 2, pp. 68-76, 2015.

[2] K. Dao, M. Ouedraogo, Y. Millogo, J.-E. Aubert, and M. Gomina, "Thermal, hydric and mechanical behaviours of adobes stabilized with cement," Constr. Build. Mater., vol. 158, pp. 84-96, 2018

[3] B. V. V. Reddy and S. R. Hubli, "Properties of lime stabilised steam-cured blocks for masonry," Mater. Struct., vol. 35, no. June, pp. 293-300, 2002.

[4] H. Houben and H. Guillaud, CRATerre: Traité de Construction en Terre: L'encyclopédie de la construction en terre, Vol. I. Marseille: Editions Parathèses, 2006.

[5] O. S. Sore, A. Messan, E. Prud, G. Escadeillas, and F. Tsobnang, "Synthesis and characterization of geopolymer binders based on local materials from Burkina Faso Metakaolin and rice husk ash," Constr. Build. Mater., vol. 124, pp. 301-311, 2016.

[6] S. Horpibulsuk, C. Phetchuay, A. Chinkulkijniwat, and A. Cholaphatsorn, "Strength development in silty clay stabilized with calcium carbide residue and fly ash," Soils Found., vol. 53, no. 4, pp. 477-486, 2013.

[7] F. A. Cardoso, H. C. Fernandes, R. G. Pileggi, M. A. Cincotto, and V. M. John, "Carbide lime and industrial hydrated lime characterization," Powder Technol., vol. 195, no. 2, pp. 143-149, 2009.

[8] B. D. Reddy, S. A. Jyothy, I. V. R. Reddy, and A. Pradesh, "Effect of Rice Husk Ash on the Properties of Ordinary Portland Cement and Portland Slag Cement With and Withou Superplasticiers," Int. J. Civil, Struct. Environ. Infrastruct. Eng. Res. Dev., vol. 3, no. 2, pp. $1-8,2013$.

[9] A. Muthadhi and S. Kothandaraman, "Optimum production conditions for reactive rice husk ash," Mater. Struct., vol. 43, no. 9, pp. 1303-1315, 2010.

[10] NF P 94-056, Sols: reconnaissance et essais-Analyse granulométrique par tamisage à sec après lavage. Saint-Denis La Plaine Cedex: AFNor, 1996.

[11] NF P 94-057, Sols: reconnaissance et essais-Analyse granulométrique des sols-Méthode par sédimentation. Saint-Denis La Plaine Cedex: AFNor, 1992.

[12] NF P 94-051, Sols: reconnaissance et essais-Détermination des limites d'Atterberg-Limite de liquidité à la coupelle-Limite de plasticité au rouleau. Saint-Denis La Plaine Cedex: AFNor, 1993.

[13] NF P 94-093, Sols: reconnaissance et essais - Détermination des références de compactage d'un matériau - Essai Proctor normal - Essai Proctor modifié. Saint-Denis La Plaine Cedex: AFNor, 1999.

[14] F. Michel and L. Courard, "Particle Size Distribution of Limestone Fillers: Granulometry and Specific Surface Area Investigations,” Part. Sci. Technol., vol. 32, no. 4, pp. 334-340, Jul. 2014.

[15] S. Brunauer, P. H. Emmett, and E. Teller, "Adsorption of gases in multimolecular layers," J. Am. Chem. Soc., vol. 60, no. 2, pp. 309-319, 1938.

[16] P. K. Mehta, "Siliceous ashes and hydraulic cements prepared therefrom, US Patent, US4105459 A, 1978

[17] XP P 13-901, Blocs de terre comprimée pour murs et cloisons, Définitions-SpécificationsMéthodes d'essais-Conditions de réception, Saint-Denis La Plaine Cedex: AFNor, 2011.

[18] M. Földvári, Handbook of the thermogravimetric system of minerals and its use in geological practice, vol. 213. Budapest: Hungarian Academy of Sciences, 2011. 
[19] H. Houben, S. Boubekeur, P. Doat, S. D’Ornano, A. Douline, P. Garnier, H. Guillaud, T. Joffroy, and V. Rigassi, Eds., Compressed Earth Blocks: Standards. Brussels-Belgium: CDI \& CRATerre-EAG, 1998 